\title{
OPTIMUM INSULATION THICKNESS FOR COLD STORAGE WALLS: CASE STUDY FOR TURKEY
}

\author{
N. Alpay KÜREKCi ${ }^{1 *}$
}

\begin{abstract}
Cold storage have heat gain resulting from walls, roof, lighting, human, cooled products, and infiltration. The biggest of these gains is the heat gain through the walls. In this study, the optimum insulation thickness which should be used on the walls of cold storage was calculated. Calculations were made for 5 cities of Turkey (Izmir, Istanbul, Ankara, Sivas, and Erzurum) with different degree-day values. Extruded polystyrene (XPS), Expanded polystyrene (EPS), glass wool, rock wool, polyurethane were chosen as insulants to be used on the walls. Cooling degree-day values of the selected cities were calculated by using the average external temperature of the cities and the cold storage temperature $(4,0,-5$, $10,-15,-20,-25$ and $-30^{\circ} \mathrm{C}$ ). Calculations were repeated for different cold storage temperature values, and optimum insulation thicknesses that should be used for each temperature were found. In addition, energy savings and payback periods when optimum insulation thickness is used were also calculated.
\end{abstract}

Keywords: Cold Storage, Optimum Insulation Thickness, Energy Saving, Thermo-Economic Analysis,
Mathematical Modeling, Thermal Insulation

\section{INTRODUCTION}

The population growth, industrialization, and the increase in per capita energy consumption has led to a steady increase in primary energy consumption globally [1]. In our world, where fossil energy resources are rapidly consumed, the importance of new and renewable energy resources is gradually increasing. The studies carried out all over the world to ensure diversification and efficient use of energy resources. Besides the efficient use of the generated energy, energy saving is also very important.

Especially for countries, such as Turkey, that are considerably dependent on external sources in terms of energy consumption, it has become imperative to reduce energy consumption rates and take necessary measures for energy saving. One of the most important factors in saving energy is insulation [2]. For this purpose, examining in detail the insulation applications of the buildings operating as residences and enterprises, and improving the insulation applications of these buildings and reducing their energy use has become one of the most popular subjects of today's construction technologies.

Another problem caused by the population growth is the food shortage. Food products are insufficient due to the increase in the number of people. Increasing agricultural and livestock products, storing these products unspoiled is an important issue. Cold storage where food products stay unspoiled are needed more and more every day. In the cold storage in Turkey, $25 \%$ to $50 \%$ of the total cost is the cost of energy [3]. Energy costs of existing facilities are increasing significantly due to the mistakes both in the planning phase of cold storage facilities used for storing various food products and mistakes in the selection and application of building materials used in these facilities. Heat gains can be high in cold storage where food products are stored or frozen due to low indoor temperatures. This results in prolonged operation of refrigerating appliances used for keeping the rooms at a certain temperature and a large amount of electrical energy consumption. Heat gains are tried to be reduced with insulation applications on walls. It is very important to choose the most suitable insulation thickness, considering the investment and operating costs [4].

Energy and environment are the two main concepts which are important about thermal insulation [5]. Energy is a strategic issue for every country. Turkey does not have much energy sources; $60-65 \%$ of its energy requirement is imported. Moreover, this requirement increases by $4 \%$ annually $[6,7]$. When the literature is examined:

Kürekci, N.A. et al. [8] calculated the optimum insulation thicknesses, payback periods and saving amounts of an externally insulated wall model for two different fuel types (natural gas, import coal) and five different insulants (rock wool, glass wool, XPS, EPS, polyurethane) for 81 provinces of Turkey. 
Özkan, D.B. and Onan C. [9] suggested the optimum insulation thicknesses for various insulants and fuel types for the 4th degree-day region in Turkey. $\mathrm{CO}_{2}$ and $\mathrm{SO}_{2}$ pollutant emissions were evaluated according to the type of insulants and fuel used.

Ozel. M. [10] calculated the optimum insulation thicknesses according to wall directions, insulant prices, energy consumption for 10 years, energy saving and payback periods for two different insulants for Elazı̆̆ province of Turkey.

Ashouri M. et al. [11] studied the optimum insulation thicknesses required for building walls via exergy analysis and life cycle assessment. Glass wool and rock wool materials were selected as insulants and the required insulation thickness, annual savings and payback periods were calculated.

Ertürk M. et al. [12] examined the optimum insulation thicknesses, annual return, payback period, flue gas emission parameters in heating-cooling applications for two different wall models, 3 different insulation materials and 3 fuel types in 16 different cities selected from the 1st and 2nd Degree-day region in Turkey.

Liu, X. et al. [13] studied the effect of moisture transfer on heating and cooling loads for buildings in Changsha, Chengdu and Shaoguan cities of China. They determined the optimum insulation thickness to be used on the walls by using the P1-P2 economic model. It was concluded that EPS insulant is more economical than XPS.

Dağıdır, C. and Bolattürk A. [14] calculated the heating and cooling loads according to the degree-hour method at a certain equilibrium temperature using the hourly temperature data recorded for many years in Meteorology for Izmir. According to these values, optimum insulation thickness required for exterior building walls in Izmir were determined by using economic data such as energy savings and payback periods, interest, inflation and lifetime.

Vincelas F.F.C. and Ghislain T. [15] calculated the optimum insulation thicknesses, energy saving and payback periods using the degree-day values for different wall models.

Derradji, L., et al. [16] studied experimentally and numerically the energy performance of a prototype building in Algeria. They found out in thermal simulation results that a good thermal insulation improves comfort and saves energy up to $70 \%$.

Ozel M. [17] determined the optimum insulation thickness to be used in Antalya in the summer period according to different wall directions.

Sanea S.A.A. and Zedan M.F. [18] optimized the insulation thicknesses of insulated building walls, which have the same thermal mass, using climatic data of Riyadh.

Daouas N. et al [19] calculated the optimum insulation thicknesses on two types of insulants and two different wall structures using the Complex Finite Fourier Transform (CFFT) method in order to reduce the energy costs of cooling loads in Tunisia.

Table 1. Summary of relevant literature according to their core of objectives

\begin{tabular}{|l|l|l|l|}
\hline Researchers & Area Investigated & Insulation Material & Thickness (m) \\
\hline Kurekci et al. [8] & Heating & $\begin{array}{l}\text { XPS,EPS, Glass wool, Rock } \\
\text { wool, Polyurethane }\end{array}$ & so many \\
\hline Özkan et al [9] & Heating & XPS, Rock wool & So many \\
\hline Ozel [10] & Heating & $\begin{array}{l}\text { XPS, } \\
\text { Polyurethane }\end{array}$ & $0.055-0.06$ \\
& & Glass wool, & $0.070-0.075$ \\
\hline Ashouri et al. [11] & Heating & Rock wool & 0.219 \\
& & XPS & 0.098 \\
\hline Ertürk et al. [12] & Heating and Cooling & XPS & $0.026-0.059$ \\
\hline Liu et al. [13] & Heating and Cooling & EPS & $0.053-0.069$ \\
& & XPS & $0.081-0.105$ \\
\hline Dağ1dır and Bolattürk [14] & Heating and Cooling & EPS & so many \\
\hline Vincelas and Ghislain [15] & Heating and Cooling & EPS, XPS, Foamed PVC, & so many \\
& & Polyurethane, Perlite, Glass & \\
\hline Derradji et al. [16] & Heating and Cooling & EPS & $0.01-0.030$ \\
\hline Ozel [17] & Cooling & XPS & $0.031-0.06$ \\
& & EPS & $0.034-0.049$ \\
\hline Sanea and Zedan [18] & Cooling & Molded polystyrene & so many \\
\hline Daouas et al [19] & Cooling & EPS, & $0.056-0.057$ \\
& & Rock wool & $0.035-0.037$ \\
\hline Nematchoua et al. [20] & Cooling & XPS & $0.08-0.11$ \\
\hline
\end{tabular}


Nematchoua. M. K. et al. [20] calculated the optimum insulation thicknesses, energy saving and payback periods in buildings for two climatic zones in Cameroon. If the literature review is tabulated according to main points emphasized in the relevant papers, the literature review can be summarized in Table 1.

When the studies are examined, it is observed that the optimum insulation thicknesses calculations, which should be used in insulation applications to reduce the heating and cooling loads of the buildings used as a residence, are performed sufficiently. However, it is observed that the optimum insulation thicknesses calculations to reduce the heat gain in the enterprises, which go down to low temperatures as in cold storage applications, are not performed sufficiently. In this study, which has been carried out to overcome this deficiency in the literature, 5 cities located in different degreeday zones of Turkey, 8 different cold storage temperatures and 5 insulation materials are selected; calculations are made in accordance with them. These values are shown in tables and graphics. In addition, annual energy saving values and payback periods are calculated. This study aims to determine the optimum insulation thickness to be used in cold storage and to reduce energy costs of such commercial enterprises.

\section{DESCRIPTION OF SYSTEM AND MATHEMATICAL MODEL External Wall Structure}

Heat gains in cold storage generally occur through external walls, roof, floors, human, product, lighting and air infiltration. In this study, the optimum insulation thicknesses has been calculated in consideration of heat gains only occurring through the external walls.

The external wall of a cold storage is externally-insulated, composed of a $2 \mathrm{~cm}$ internal plaster, $20 \mathrm{~cm}$ porous concrete block, insulant and a $3 \mathrm{~cm}$ external plaster as shown in Figure 1 below. Physical characteristics of constituents of the wall are given in Table 1. In calculations, only heat gains occurring through external walls were considered to calculate the optimum insulation thicknesses.

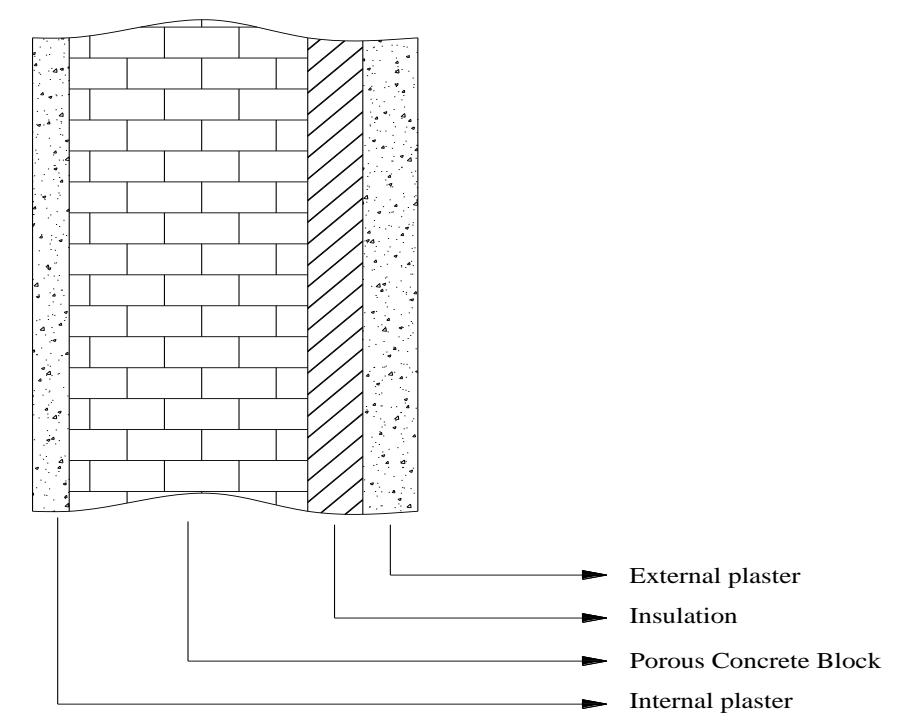

Figure 1. External wall structure

Table 2. Physical properties of the materials of external wall [21]

\begin{tabular}{|l|c|c|c|}
\hline \multicolumn{1}{|c|}{ Wall structure } & $\begin{array}{c}\text { Thickness } \\
(\mathrm{m})\end{array}$ & $\begin{array}{c}\mathrm{k} \\
(\mathrm{W} / \mathrm{mK})\end{array}$ & $\begin{array}{c}\mathrm{R} \\
\left(\mathrm{m}^{2} \mathrm{~K} / \mathrm{W}\right)\end{array}$ \\
\hline Internal Plaster (Lime-based) & 0.02 & 1.0 & 0.020 \\
\hline Porous concrete block & 0.20 & 0.22 & 0.909 \\
\hline External plaster (cement-based) & 0.03 & 1.6 & 0.019 \\
\hline $\mathrm{R}_{\mathrm{i}}$ & & & 0.13 \\
\hline $\mathrm{R}_{\mathrm{o}}$ & & & 0.04 \\
\hline $\mathrm{R}_{\mathrm{wt}}$ & & & 1.118 \\
\hline
\end{tabular}


The external cold storage wall is externally insulated as shown in Figure 1. It consists of $2 \mathrm{~cm}$ internal plaster, $20 \mathrm{~cm}$ porous concrete block, insulant material and a $3 \mathrm{~cm}$ external plaster. Physical characteristics of constituents of the wall are given in Table 2. In calculations, only the heat gains occurring through external walls were considered to calculate the optimum insulation thicknesses.

In this paper, optimum insulation thicknesses of a cold storage external wall were calculated for cooling in five cities in Turkey using five different insulation materials (Table 3). Price of electricity used in the study and COP (Coefficient of Performance) are shown in Table 4. Labor costs vary from one city to another. Therefore, labor costs are not taken into account for the correct comparison. Life cycle, interest and inflation values employed in calculating the present worth factor are summarized in Table 5 .

Table 3. Parameters of the insulation wall [22]

\begin{tabular}{|l|c|c|}
\hline Insulation & $\begin{array}{c}\mathrm{k} \\
(\mathrm{W} / \mathrm{mK})\end{array}$ & $\begin{array}{c}\mathrm{C}_{\mathrm{y}} \\
\left(\$ / \mathrm{m}^{3}\right)\end{array}$ \\
\hline Extruded polystyrene (XPS) & 0.030 & 90 \\
\hline Expanded polystyrene (EPS) & 0.039 & 40 \\
\hline Glass wool & 0.033 & 45 \\
\hline Rock wool & 0.037 & 80 \\
\hline Polyurethane & 0.024 & 235 \\
\hline
\end{tabular}

Table 4. COP and price of electricity

\begin{tabular}{|l|l|}
\hline COP & 3.0 \\
\hline Electricity Price [23] $\left(\mathrm{C}_{\mathrm{e}}\right)$ & $0.07077 \$ / \mathrm{kWh}$ \\
\hline
\end{tabular}

Table 5. Parameters used in the calculations

\begin{tabular}{|l|c|}
\hline Rate of interest (i) & $23 \%$ \\
\hline Inflation rate [24] (g) & $17.9 \%$ \\
\hline Life cycle (N) & 10 years \\
\hline Present Worth Factor (PWF) & 7.98 \\
\hline
\end{tabular}

The average external temperatures of the selected cities between 1927-2017 were measured by the General Directorate of Meteorology and given in Table 6.

Table 6. Average external weather temperatures of cities between $1927-2017$ years $\left({ }^{\circ} \mathrm{C}\right)[25]$

\begin{tabular}{|c|c|c|c|c|c|c|c|c|c|c|c|c|c|}
\hline City & Jan. & Feb. & Mar. & Apr. & May. & Jun. & Jul. & Aug. & Sep. & Oct. & Nov. & Dec. & Annual Ave. \\
\hline Izmir & 8.7 & 9.5 & 11.6 & 15.8 & 20.7 & 25.5 & 28.0 & 27.6 & 23.6 & 18.7 & 14.0 & 10.4 & 17.8 \\
\hline Istanbul & 6.0 & 6.1 & 7.7 & 12.0 & 16.7 & 21.4 & 23.8 & 23.8 & 20.1 & 15.7 & 11.7 & 8.3 & 14.4 \\
\hline Ankara & 0.2 & 1.6 & 5.7 & 11.3 & 16.1 & 20.1 & 23.5 & 23.4 & 18.8 & 12.9 & 7.1 & 2.4 & 11.9 \\
\hline Sivas & -3.5 & -2.2 & 2.6 & 8.8 & 13.5 & 17.0 & 20.0 & 20.1 & 16.1 & 10.7 & 4.7 & -0.7 & 8.9 \\
\hline Erzurum & -9.2 & -7.7 & -2.5 & 5.3 & 10.7 & 14.9 & 19.3 & 19.5 & 14.7 & 8.1 & 1.0 & -6.0 & 5.7 \\
\hline
\end{tabular}

\section{Cooling Load for External Walls}

Heat transferring through a unit surface of external wall is calculated as in Eq 1.

$$
q=U \cdot \Delta T
$$

$\mathrm{U}$ is heat transfer coefficient and $\Delta \mathrm{T}$ is the temperature difference between outside ambient and constant indoor temperature. Correspondingly, annual heat gain through a unit surface is calculated with $U$ and degree-day value [4]. 


$$
q_{\text {year }, c}=86400 \cdot C D D \cdot U
$$

CDD in the formula is Coiling Degree-day value and it is calculated with the formula below [26].

$$
C D D=\Sigma\left(T_{0}-T_{r}\right)
$$

$\mathrm{T}_{0}$ in the formula is the average exterior temperature (Table 5); $\mathrm{T}_{\mathrm{r}}$ is the reference temperatures of cold storage. In this study, $\mathrm{T}_{\mathrm{r}}=+4,0,-5,-10,-15,-20,-25$ and $-30^{\circ} \mathrm{C}$.

Overall heat transfer coefficient for a plane wall:

$$
U=\frac{1}{R_{i}+R_{w}+R_{\text {ins }}+R_{0}}
$$

$R_{i}$ and $R_{o}$ are the heat transfer resistance of the inside and outside environment respectively and $R_{w}$ is the heat transfer resistance of wall layers without heat insulation. $R_{\text {ins }}$ is the thermal resistance of the insulant and calculated as follows:

$$
R_{\text {ins }}=\frac{x}{k}
$$

$\mathrm{x}$ and $\mathrm{k}$ are the thickness and thermal conductivity of insulation respectively. Total resistance of the non-insulated wall layer $R_{w . t}$ is

$$
R_{w, t}=R_{i}+R_{w}+R_{0}
$$

Then, total heat transfer coefficient $\mathrm{U}$ is expressed as

$$
U=\frac{1}{R_{w, t}+R_{\text {ins }}}
$$

Annual energy requirement for cooling $E_{y e a r c,}$ is calculated as in Eq 8.

$$
E_{y e a r, c}=\frac{86400 \cdot C D D}{\left(R_{w, t}+R_{\text {ins }}\right) \cdot C O P}
$$

The COP means cooling system coefficient of performance.

\section{Optimum Insulation Thickness and Annular Cost of Energy Calculation}

Insulating external walls of the cold storage reduced the heat gain through the building surface significantly. But, determination of optimum insulation thicknesses requires a cost analysis. Annual energy cost for unit surface $\mathrm{C}_{\mathrm{A}, \mathrm{c}}$ is calculated as follows:

$$
C_{A, c}=\frac{86400 \cdot C D D \cdot C_{e}}{\left(R_{w, t}+R_{\text {ins }}\right) \cdot C O P}
$$

$\mathrm{C}_{\mathrm{e}}$ is the cost of electricity (Table 3 ).

The life cycle cost analysis method is employed to evaluate the optimum insulation thicknesses. Annual energy cost was calculated based upon the present worth factor and the lifetime determined [4, 12]. The present worth factor is calculated based upon the inflation and interest rates as follows: 


$$
\begin{aligned}
& \text { If } \mathrm{i}>\mathrm{g}: \quad r=\frac{i-g}{1+g} \\
& \text { If } \mathrm{g}>\mathrm{i}: \quad \\
& P W F=\frac{(1+r)^{N}-1}{r \cdot(1+r)^{N}} \\
& \text { If } \mathrm{i}=\mathrm{g}: \quad
\end{aligned}
$$

PWF is the present worth factor, $\mathrm{i}$ is the interest rate, $\mathrm{g}$ is the inflation rate, $\mathrm{r}$ is actual interest rate and $\mathrm{N}$ is the lifetime. Insulation cost is calculated as in Eq 14:

$$
C_{\text {ins }}=C_{y} \cdot x
$$

Eventually, the total cooling cost of an insulated building as per the life cycle cost analysis is:

$$
C_{t, C}=C_{A, C} \cdot P W F+C_{y} \cdot x
$$

Optimum insulation thicknesses minimizing the total cooling cost is calculated with the equation below [20].

$$
x_{o p t, C}=293.94\left(\frac{C D D \cdot C_{e} \cdot P W F \cdot k}{C_{y} \cdot C O P}\right)^{1 / 2}-k \cdot R_{w, t}
$$

\section{Payback Period}

Annual total net saving amount for cold storage cooled is calculated with formula 17 . The $\mathrm{C}_{\mathrm{c}}$ is non-insulation cooling energy costs:

$$
A_{\text {year }, C}=C_{c}-C_{t, c}
$$

Payback period:

$$
p p_{c}=\frac{C_{\text {ins }}}{A_{\text {year }, C}}
$$

\section{RESULTS AND DISCUSSION}

Cooling degree-day values of the selected cities are calculated with the formula 3 by using the average exterior temperatures recorded between 1927 and 2017 and are stated in the Table 7. When the cooling degree-day values of the cities are examined, the lowest cooling degree-day value is found in Erzurum for $+4^{\circ} \mathrm{C}$ as $1977{ }^{\circ} \mathrm{C}$.day and the highest cooling degree-day value is found in Izmir for $-30^{\circ} \mathrm{C}$ with $17480{ }^{\circ} \mathrm{C}$.day.

Increasing, insulation thickness leads to increase in initial investment cost, but decreases operating costs. In this study, optimum insulation thicknesses of a cold storage external wall for five insulant materials were calculated based on cooling degree-day values for five cities in Turkey.

Insulation cost, electricity cost, and total cost graphs are drawn for 5 selected cities and 5 different insulants. For example, the graph for 5 insulants that can be used in Ankara and $0^{\circ} \mathrm{C}$ cold storage temperature is given in Figure 2. When the graphs are examined, it is seen that the optimum insulation thicknesses is the thinnest in polyurethane material and the thickest in EPS material. Optimum insulation thicknesses are found to be 0.095, 0.084, 0.054, 0.048 and $0.018 \mathrm{~m}$ for EPS, Glass wool, Rock wool, XPS and polyurethane materials respectively. 
Journal of Thermal Engineering, Research Article, Vol. 6, No. 5, pp. 873-887, October, 2020

Table 7. Coiling degree-day reference temperatures of cold storage $\left({ }^{\circ} \mathrm{C}\right.$.days $)$

\begin{tabular}{|l|l|l|l|l|l|l|l|l|}
\hline \multicolumn{7}{|c|}{ Reference Temperature of Cold Storage $\mathrm{T}_{\mathrm{r}}\left({ }^{\circ} \mathrm{C}\right)$} \\
\hline City & 4 & 0 & -5 & -10 & -15 & -20 & -25 & -30 \\
\hline Izmir & 5070 & 6530 & 8355 & 10180 & 12005 & 13830 & 15655 & 17480 \\
\hline Istanbul & 3829 & 5289 & 7114 & 8939 & 10764 & 12589 & 14414 & 16239 \\
\hline Ankara & 3149 & 4374 & 6199 & 8024 & 9849 & 11674 & 13499 & 15324 \\
\hline Sivas & 2415 & 3472 & 5105 & 6930 & 8755 & 10580 & 12405 & 14230 \\
\hline Erzurum & 1977 & 2863 & 4160 & 5748 & 7573 & 9398 & 11223 & 13048 \\
\hline
\end{tabular}

Ankara XPS

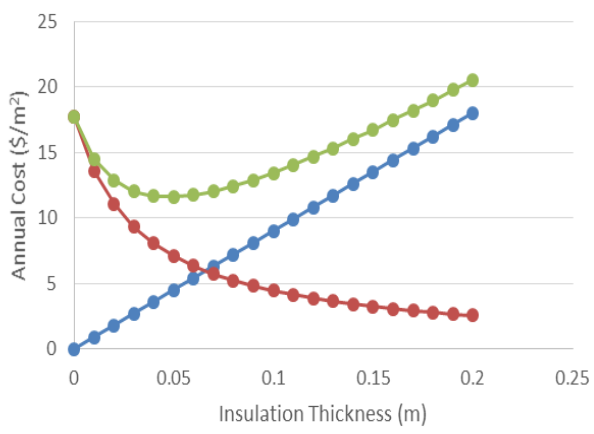

Ankara Glass Wool

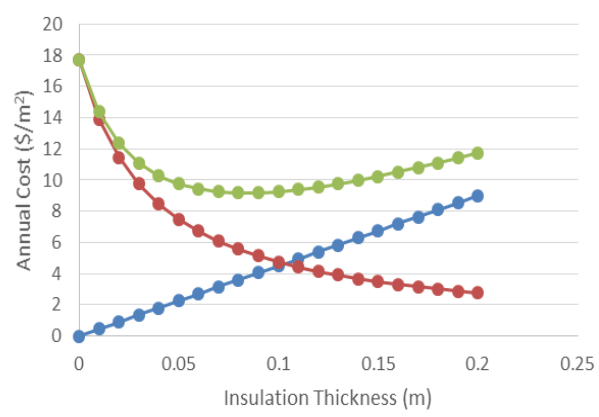

Ankara EPS

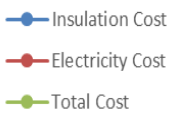

$\rightarrow-$ Insulation Cost

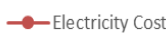

$\rightarrow$ Total Cost

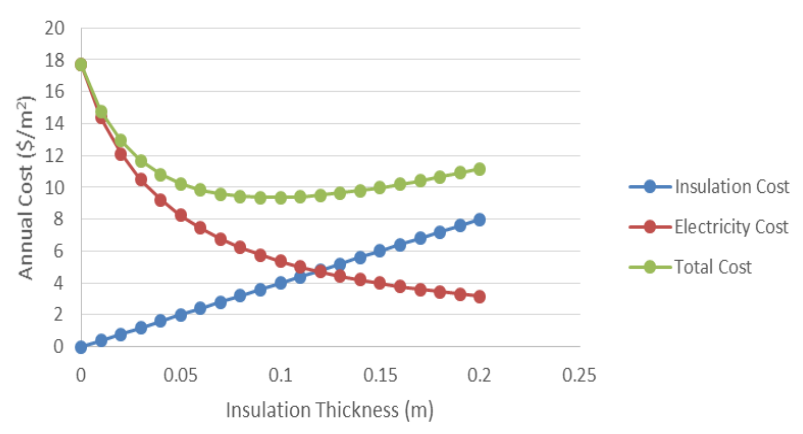

Ankara Rock Wool

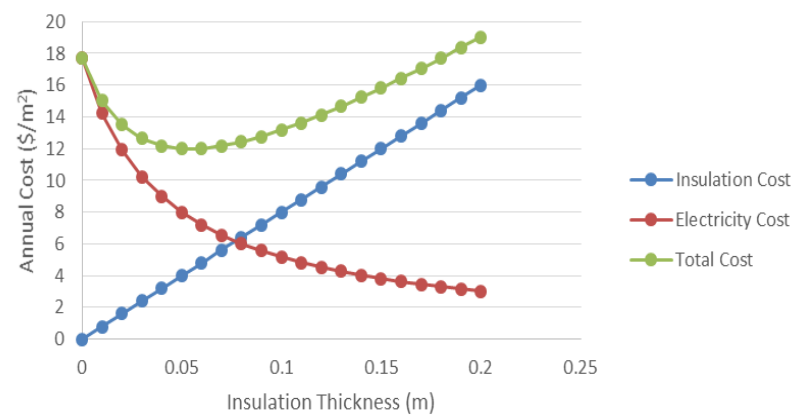

Ankara Polyurethane

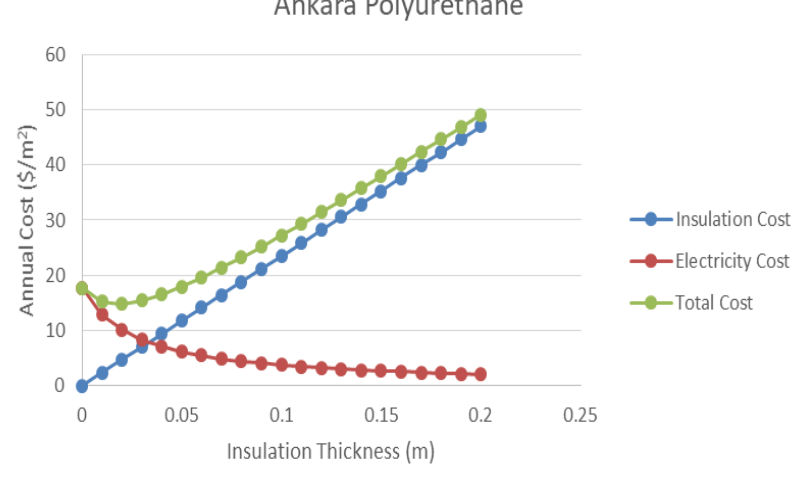

Figure 2. Optimum insulation thicknesses calculated according to insulants for $0^{\circ} \mathrm{C}$ cold storage temperature in Ankara

Optimum insulation thicknesses, which must be used according to different insulants and different cold storage temperatures for 5 selected cities, are calculated using Formula 16 and are given in Table 8. In Izmir, where the average exterior temperature is the highest among the selected cities, optimum insulation thickness are calculated to be the highest as expected. The lowest insulation thickness was calculated in Erzurum. 
Journal of Thermal Engineering, Research Article, Vol. 6, No. 5, pp. 873-887, October, 2020

Table 8. Optimum insulation thicknesses to be used according to cold storage temperatures in the selected cities

\begin{tabular}{|c|c|c|c|c|c|c|}
\hline & $T_{r}$ & EPS & Glass Wool & Rock Wool & XPS & Polyurethane \\
\hline \multirow{8}{*}{ Izmir } & $4^{\circ} \mathrm{C}$ & 0.106 & 0.093 & 0.062 & 0.054 & 0.022 \\
\hline & $0^{\circ} \mathrm{C}$ & 0.126 & 0.110 & 0.075 & 0.066 & 0.028 \\
\hline & $-5^{\circ} \mathrm{C}$ & 0.148 & 0.129 & 0.091 & 0.079 & 0.035 \\
\hline & $-10^{\circ} \mathrm{C}$ & 0.168 & 0.147 & 0.104 & 0.090 & 0.042 \\
\hline & $-15^{\circ} \mathrm{C}$ & 0.186 & 0.163 & 0.117 & 0.101 & 0.048 \\
\hline & $-20^{\circ} \mathrm{C}$ & 0.203 & 0.177 & 0.129 & 0.111 & 0.053 \\
\hline & $-25^{\circ} \mathrm{C}$ & 0.219 & 0.191 & 0.140 & 0.120 & 0.058 \\
\hline & $-30^{\circ} \mathrm{C}$ & 0.234 & 0.204 & 0.150 & 0.129 & 0.063 \\
\hline \multirow{8}{*}{ Istanbul } & $4^{\circ} \mathrm{C}$ & 0.086 & 0.076 & 0.048 & 0.042 & 0.015 \\
\hline & $0^{\circ} \mathrm{C}$ & 0.109 & 0.095 & 0.064 & 0.056 & 0.023 \\
\hline & $-5^{\circ} \mathrm{C}$ & 0.133 & 0.117 & 0.081 & 0.070 & 0.030 \\
\hline & $-10^{\circ} \mathrm{C}$ & 0.155 & 0.135 & 0.095 & 0.082 & 0.037 \\
\hline & $-15^{\circ} \mathrm{C}$ & 0.174 & 0.152 & 0.109 & 0.094 & 0.044 \\
\hline & $-20^{\circ} \mathrm{C}$ & 0.192 & 0.167 & 0.121 & 0.104 & 0.049 \\
\hline & $-25^{\circ} \mathrm{C}$ & 0.208 & 0.182 & 0.132 & 0.114 & 0.055 \\
\hline & $-30^{\circ} \mathrm{C}$ & 0.224 & 0.195 & 0.143 & 0.123 & 0.060 \\
\hline \multirow{8}{*}{ Ankara } & $4^{\circ} \mathrm{C}$ & 0.074 & 0.065 & 0.040 & 0.035 & 0.011 \\
\hline & $0^{\circ} \mathrm{C}$ & 0.095 & 0.084 & 0.054 & 0.048 & 0.018 \\
\hline & $-5^{\circ} \mathrm{C}$ & 0.122 & 0.106 & 0.072 & 0.063 & 0.027 \\
\hline & $-10^{\circ} \mathrm{C}$ & 0.144 & 0.126 & 0.088 & 0.076 & 0.034 \\
\hline & $-15^{\circ} \mathrm{C}$ & 0.165 & 0.144 & 0.102 & 0.088 & 0.041 \\
\hline & $-20^{\circ} \mathrm{C}$ & 0.183 & 0.160 & 0.115 & 0.099 & 0.047 \\
\hline & $-25^{\circ} \mathrm{C}$ & 0.200 & 0.175 & 0.127 & 0.109 & 0.052 \\
\hline & $-30^{\circ} \mathrm{C}$ & 0.216 & 0.188 & 0.138 & 0.118 & 0.057 \\
\hline \multirow{8}{*}{ Sivas } & $4^{\circ} \mathrm{C}$ & 0.060 & 0.053 & 0.030 & 0.027 & 0.007 \\
\hline & $0^{\circ} \mathrm{C}$ & 0.080 & 0.070 & 0.044 & 0.039 & 0.013 \\
\hline & $-5^{\circ} \mathrm{C}$ & 0.106 & 0.093 & 0.062 & 0.054 & 0.022 \\
\hline & $-10^{\circ} \mathrm{C}$ & 0.131 & 0.115 & 0.079 & 0.069 & 0.030 \\
\hline & $-15^{\circ} \mathrm{C}$ & 0.153 & 0.133 & 0.094 & 0.081 & 0.037 \\
\hline & $-20^{\circ} \mathrm{C}$ & 0.172 & 0.150 & 0.107 & 0.093 & 0.043 \\
\hline & $-25^{\circ} \mathrm{C}$ & 0.190 & 0.166 & 0.120 & 0.103 & 0.049 \\
\hline & $-30^{\circ} \mathrm{C}$ & 0.207 & 0.180 & 0.131 & 0.113 & 0.054 \\
\hline \multirow{8}{*}{ Erzurum } & $4^{\circ} \mathrm{C}$ & 0.050 & 0.044 & 0.023 & 0.021 & 0.003 \\
\hline & $0^{\circ} \mathrm{C}$ & 0.069 & 0.061 & 0.036 & 0.032 & 0.010 \\
\hline & $-5^{\circ} \mathrm{C}$ & 0.092 & 0.081 & 0.052 & 0.046 & 0.017 \\
\hline & $-10^{\circ} \mathrm{C}$ & 0.116 & 0.101 & 0.068 & 0.060 & 0.025 \\
\hline & $-15^{\circ} \mathrm{C}$ & 0.139 & 0.122 & 0.084 & 0.073 & 0.032 \\
\hline & $-20^{\circ} \mathrm{C}$ & 0.160 & 0.140 & 0.099 & 0.085 & 0.039 \\
\hline & $-25^{\circ} \mathrm{C}$ & 0.179 & 0.156 & 0.112 & 0.096 & 0.045 \\
\hline & $-30^{\circ} \mathrm{C}$ & 0.196 & 0.171 & 0.124 & 0.107 & 0.051 \\
\hline
\end{tabular}



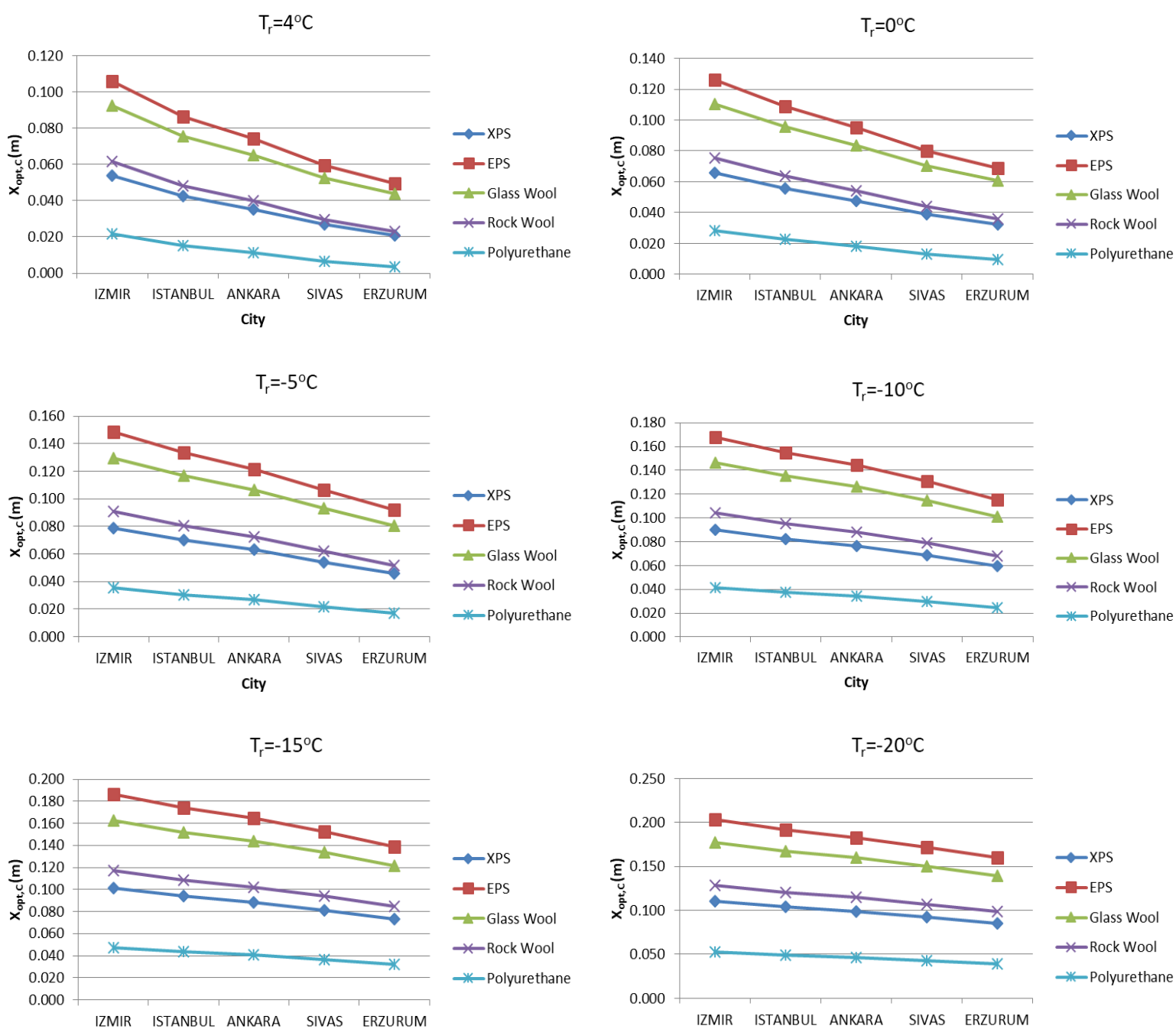

City
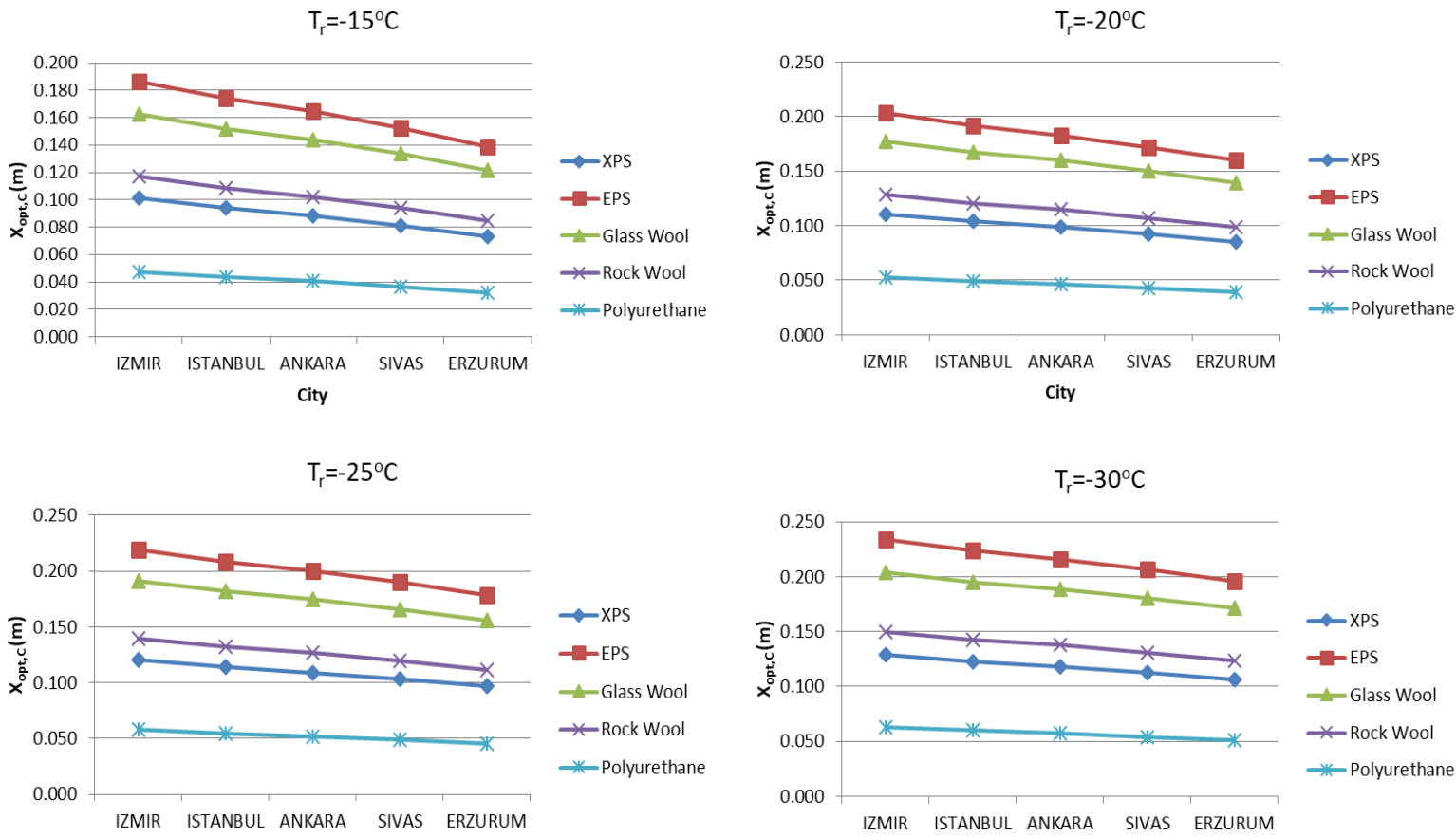

City

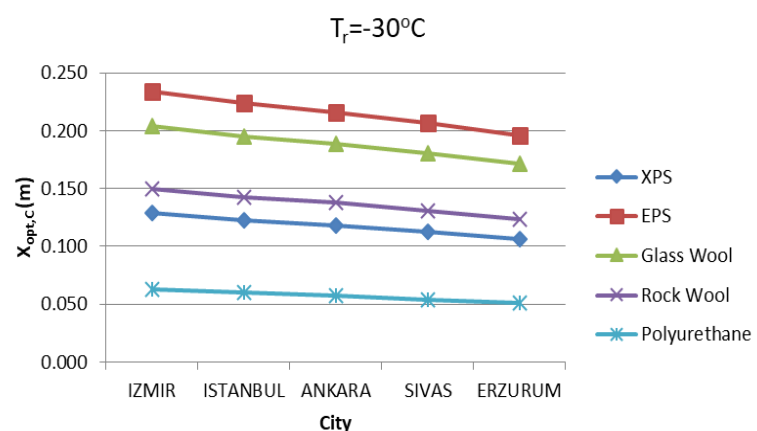

Figure 3. Optimum insulation thickness calculated according to 8 different cold storage temperatures and 5 different insulants in the 5 selected cities

For all insulants, the required insulation thickness increases as the cold storage temperature decreases. At the same time, the required insulation thickness decreases as the average external temperature decreases (Figure 3).

Optimum insulation thicknesses that should be used according to the insulant type and different cold storage temperatures for the 5 selected cities are given in Figure 4. 
Journal of Thermal Engineering, Research Article, Vol. 6, No. 5, pp. 873-887, October, 2020

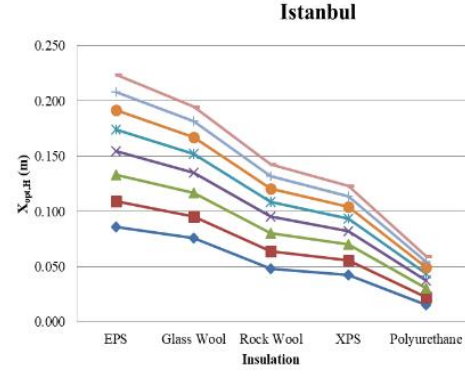

Ankara

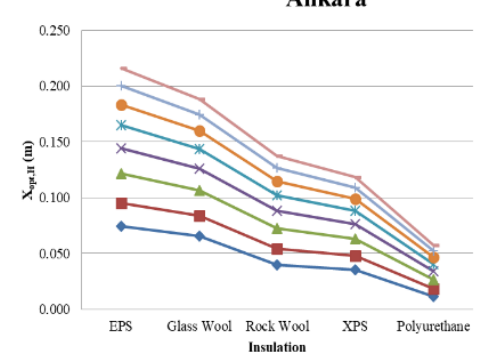

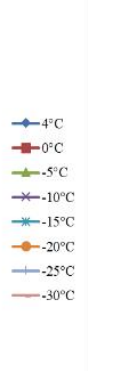

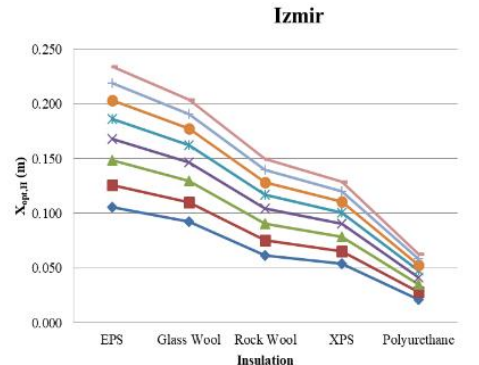

Sivas

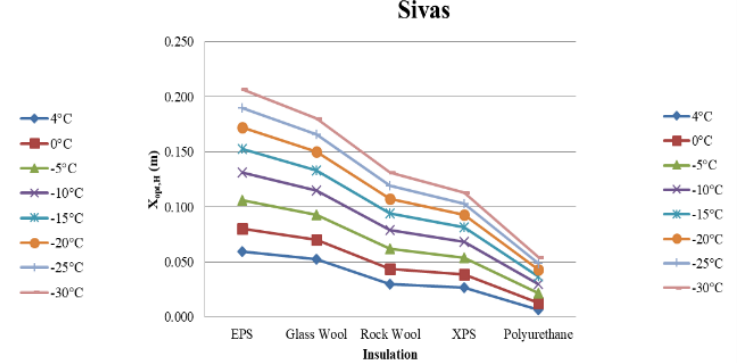

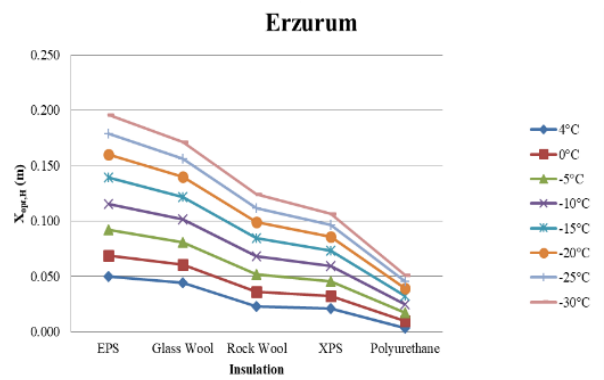

Figure 4. Optimum insulation thickness calculated based on insulants for cold storage temperatures of $+4,0,-5,-10$, $15,-20,-25$ and $-30^{\circ} \mathrm{C}$ according to the cities
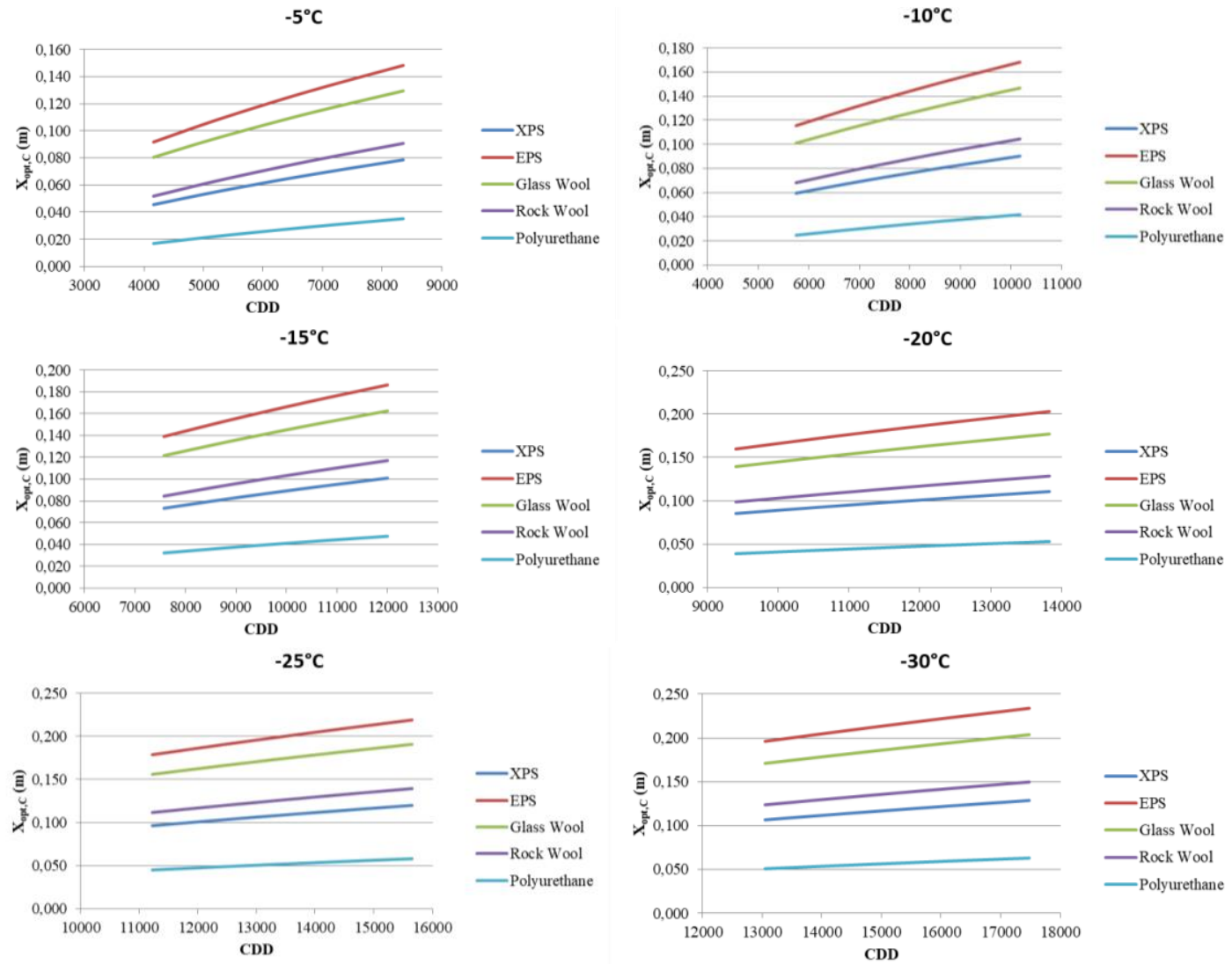

Figure 5. Optimum insulation thicknesses of insulants according to cooling degree-day values for different cold storage temperatures 
A more general table is created by using the calculated cooling degree-day values in order to use the values found outside the 5 selected cities. Figure 5 shows the optimum insulation thicknesses of insulants according to the cooling degree-day values for different cold storage temperatures. As the cooling degree-day value increases and the cold storage temperature decreases, the required insulant thickness increases. The order of insulants varies according to the material price and heat transfer coefficient. The thinnest insulant to be used was Polyurethane. XPS, rock wool, glass wool, and EPS followed respectively.
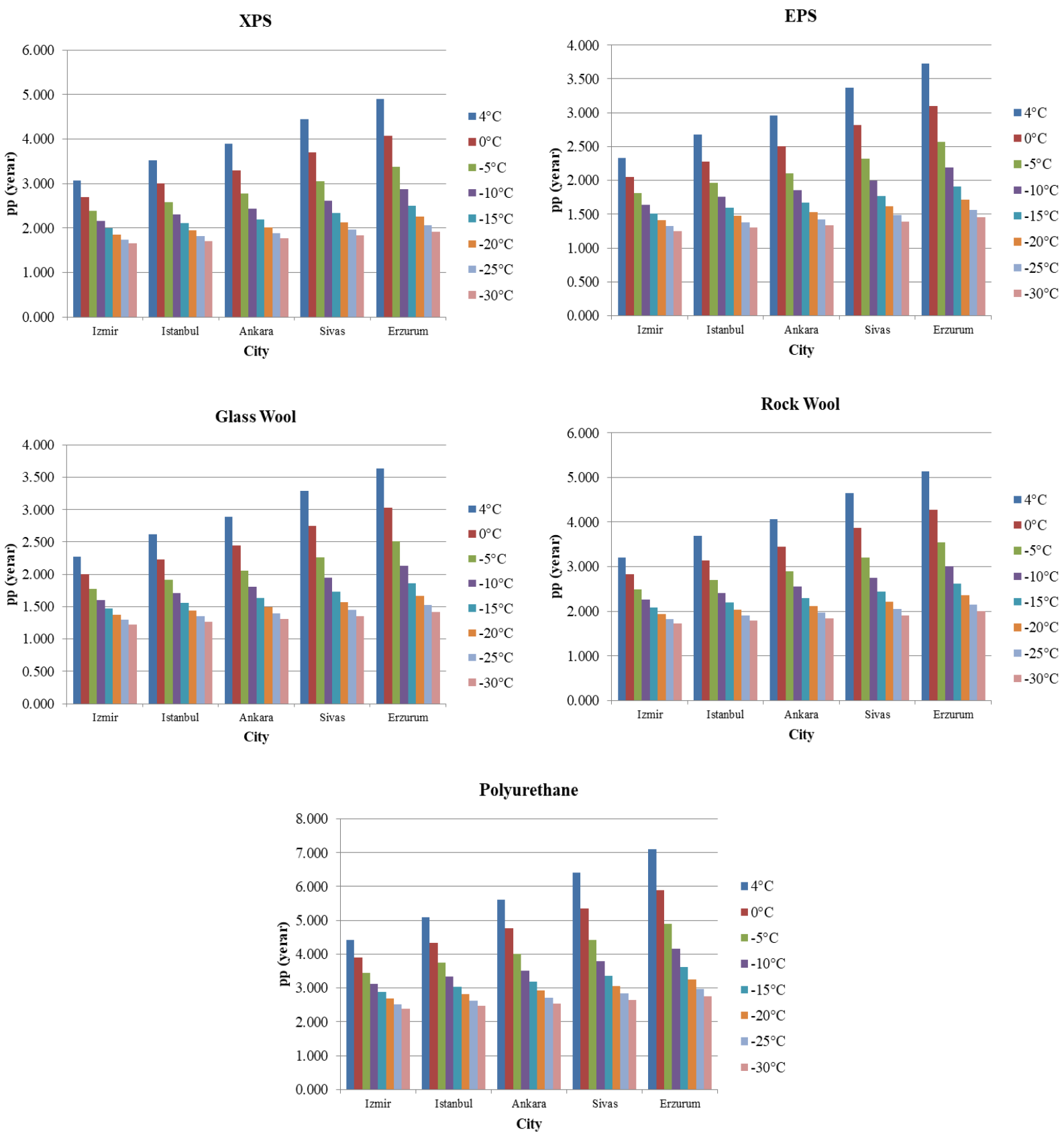

Figure 6. Payback periods of the insulants to be used for 8 different cold storage temperatures and 5 different cities

Payback periods of the insulants to be used according to the calculated optimum insulation thicknesses were calculated. In all insulants, payback period decreases as the cold storage temperature decreases. The payback periods from the shortest to the longest respectively are glass wool, EPS, XPS, rock wool and polyurethane (Figure 6). 


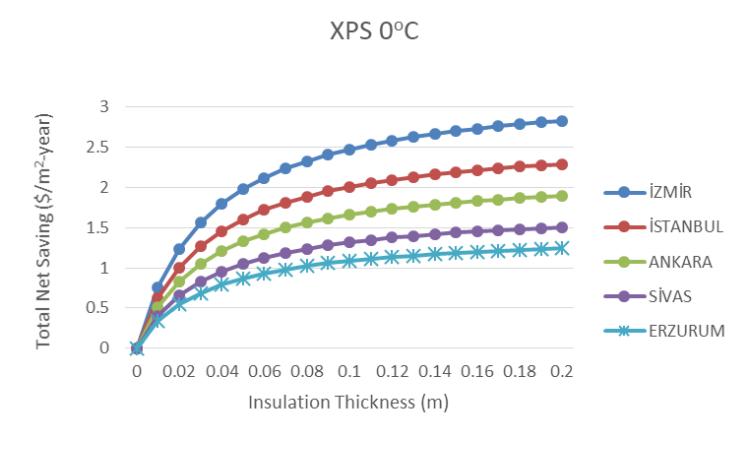

Glass Wool $0^{\circ} \mathrm{C}$

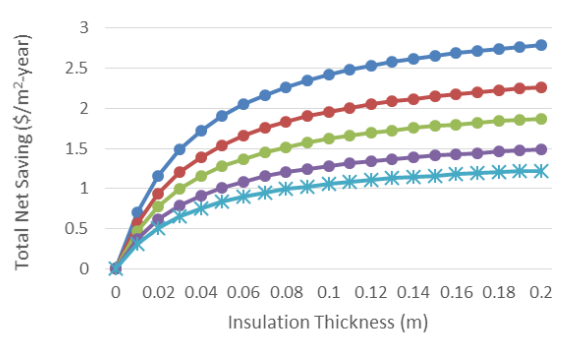

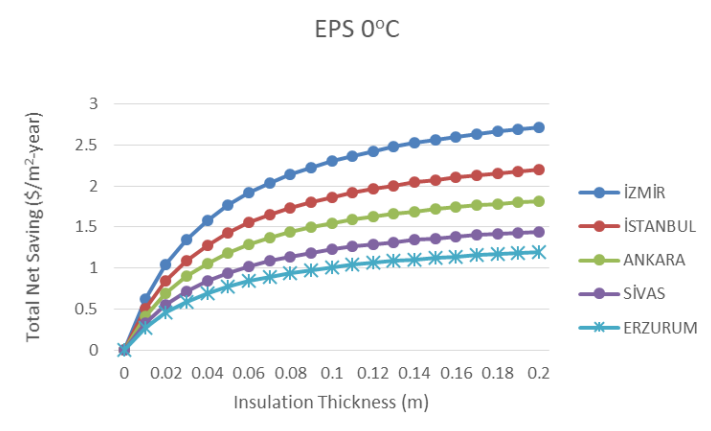

Rock Wool $0^{\circ} \mathrm{C}$

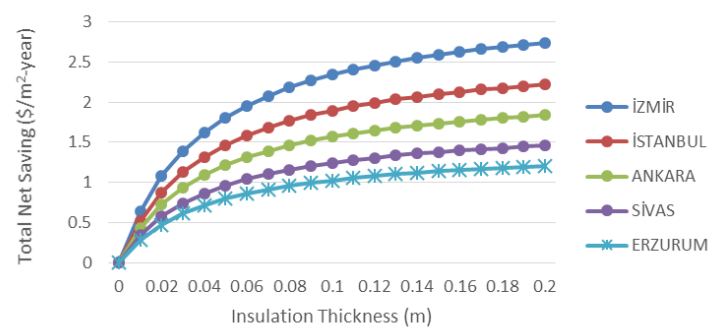

Polyurethane $0^{\circ} \mathrm{C}$

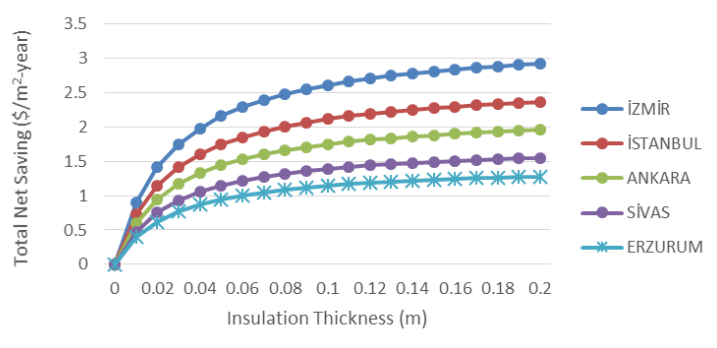

Figure 7. Total net saving values according to the thickness to be used for $0^{\circ} \mathrm{C}$ cold storage temperature, 5 cities and 5 different insulants

Figure 7 shows the annual saving changes calculated for the 5 selected cities, $0^{\circ} \mathrm{C}$ cold storage temperature and 5 insulants. As the insulation thickness increases, the annual saving amount increases parabolically. The highest saving is observed in Izmir, followed by Istanbul, Ankara, Sivas, and Erzurum respectively.

EPS

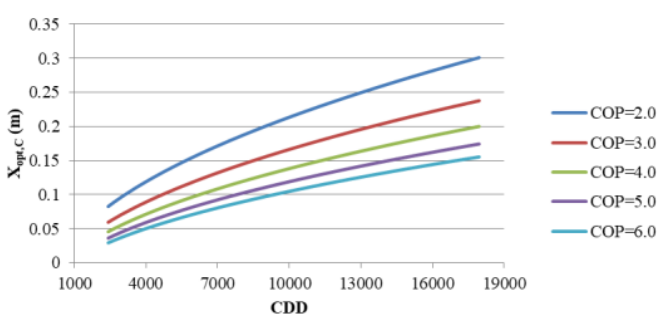

Figure 8. The effect of COP value on the optimum insulation thickness for EPS insulation material

Calculations were based on an assumed COP value of 3 for the cooling system used in the cold store. Changes in COP value lead to changes in the optimum insulation thickness. To analyze this change, calculations were repeated for EPS insulation material at 1 increments in the range of COP values between 2.0-6.0 for the interval of $2410-17956{ }^{\circ} \mathrm{C}$.day values, and the results are summarized in Fig 8. The Figure indicates that, for all COP values, optimum insulation thickness increases with increasing CDD values. For all CDD values, optimum insulation thickness decreases with increasing COP values. 


\section{CONCLUSION}

The efficient use of energy increases in importance every day. Insulation for heating and cooling of a room affects the energy to be consumed. In this study, the thicknesses of insulants, which should be used in order to reduce the energy consumption for the cooling of cold storage where different foods are stored, are calculated. The initial investment cost of insulants increases according to thickness. Besides, increasing the insulation thickness decreases energy consumption. In this study, the overall cost values which are the total initial investment costs and operating costs are calculated. Optimum insulation thicknesses with the minimum total cost curve were calculated according to the selected insulants and selected cold storage temperatures in the selected cities. The payback periods and annual energy saving amounts of the insulants with an optimum thickness to be used are calculated.

As a result of the calculations:

- The required optimum insulation thicknesses increases as the cooling degree-day value increases.

- The required optimum insulation thicknesses increases as the cold storage temperature decreases.

- Considering the selected cities, the thinnest insulant should be used in Erzurum and the thickest insulant should be used in Izmir for all insulants.

- For all of the selected cities and selected cold storage temperatures, the thinnest insulation material was calculated as polyurethane, followed by XPS, rock wool, glass wool, and EPS respectively.

- Optimum insulation thicknesses at $0^{\circ} \mathrm{C}$ cold storage temperature in Izmir was found as $0.126,0.110,0.075$, 0.066, $0.028 \mathrm{~m}$ for EPS, glass wool, rock wool, XPS and polyurethane respectively.

- Optimum insulation thicknesses at $0^{\circ} \mathrm{C}$ cold storage temperature in Istanbul was found as $0.109,0.095$, $0.064,0.056,0.023 \mathrm{~m}$ for EPS, glass wool, rock wool, XPS and polyurethane respectively.

- Optimum insulation thicknesses at $0^{\circ} \mathrm{C}$ cold storage temperature in Ankara was found as $0.095,0.084$, $0.054,0.048,0.018 \mathrm{~m}$ for EPS, glass wool, rock wool, XPS and polyurethane respectively.

- Optimum insulation thicknesses at $0^{\circ} \mathrm{C}$ cold storage temperature in Sivas was found as $0.080,0.070,0.044$, 0.039, $0.013 \mathrm{~m}$ for EPS, glass wool, rock wool, XPS and polyurethane respectively.

- Optimum insulation thicknesses at $0^{\circ} \mathrm{C}$ cold storage temperature in Erzurum was found as 0.069, 0.061, 0.036, 0.032, $0.010 \mathrm{~m}$ for EPS, glass wool, rock wool, XPS and polyurethane respectively.

- When the payback periods are examined, glass wool has the shortest payback period followed by EPS, XPS, rock wool and polyurethane respectively.

- When the total annual net saving values are examined, the highest saving is made in Izmir, followed by Istanbul, Ankara, Sivas, and Erzurum respectively.

- The COP value of the selected cooling system is a factor in determining the recommended insulation thickness. As the COP value gets smaller, the recommended insulation material thickness increases.

Calculations were made using certain assumptions and current prices. If prices change, the results will change. Although it depends on the insulant to be used, the initial investment cost of insulants to be used in cold storage pays off in a short time. Payback periods are quite short. As the labor costs are not calculated when calculating the initial investment cost, the payback period will definitely increase slightly. If the optimum insulation thicknesses found by calculations are used, there will be a significant decrease in the amount and cost of the energy to be consumed in cold storage to keep products unspoiled. The importance of insulation is understood yet again if we consider the environmental pollution to be caused by thermal power plants to generate the electric power to be used [27-28].

\section{NOMENCLATURE}

$\begin{array}{ll}\mathrm{A}_{\text {year,C }} & \text { Annual total cooling cost, }\left(\$ / \mathrm{m}^{2} \text { year }\right) \\ \mathrm{C} & \text { Annual energy cost for unit surface without insulated, }\left(\$ / \mathrm{m}^{2} \text { year }\right) \\ \mathrm{C}_{\mathrm{A}, \mathrm{C}} & \text { Total cooling cost, }\left(\$ / \mathrm{m}^{2} \text { year }\right) \\ \mathrm{C}_{\mathrm{c}} & \text { Non-insulation cooling energy costs } \\ \mathrm{CDD} & \text { Cooling Degree-Day value, }\left({ }^{\circ} \mathrm{C} \text {-days }\right) \\ \mathrm{C}_{\mathrm{e}} & \text { Electricity Price } \\ \mathrm{C}_{\mathrm{ins}} & \text { Cost of the insulating material, }\left(\$ / \mathrm{m}^{2}\right) \\ \mathrm{COP} & \text { Coefficient of Performance }\end{array}$


$\mathrm{C}_{\mathrm{t}, \mathrm{C}} \quad$ Total cooling cost of the insulated cold storage, $\left(\$ / \mathrm{m}^{2}\right.$ year $)$

$\mathrm{C}_{\mathrm{y}} \quad$ Cost of the insulant material $\left(\$ / \mathrm{m}^{3}\right)$

$\Delta \mathrm{T} \quad$ Temperature difference $(\mathrm{K})$

EPS Expanded polystyrene

$E_{y e a r, C}$ Annual energy need for cooling cold storage $\left(\mathrm{J} / \mathrm{m}^{2}\right.$ year $)$

g Inflation, (\%)

i Interest, (\%)

$\mathrm{k}$ Thermal conductivity of insulation material, $(\mathrm{W} / \mathrm{mK})$

N Service time, (year)

pp Payback period (year)

PWF Present Worth Factor

q Annual heat loss, $\left(\mathrm{W} / \mathrm{m}^{2}\right)$

$\mathrm{r} \quad$ Actual interest rate

$\mathrm{R} \quad$ Heat transfer resistance, $\left(\mathrm{m}^{2} \mathrm{~K} / \mathrm{W}\right)$

$\mathrm{R}_{\mathrm{i}} \quad$ Inside heat transfer resistance, $\left(\mathrm{m}^{2} \mathrm{~K} / \mathrm{W}\right)$

$R_{\text {ins. }} \quad$ Thermal resistance of the insulant material, $\left(m^{2} \mathrm{~K} / \mathrm{W}\right)$

$\mathrm{R}_{0} \quad$ Outside heat transfer resistance, $\left(\mathrm{m}^{2} \mathrm{~K} / \mathrm{W}\right)$

$\mathrm{R}_{\mathrm{w}} \quad$ Thermal resistance of wall layers without insulation, $\left(\mathrm{m}^{2} \mathrm{~K} / \mathrm{W}\right)$

$\mathrm{R}_{\mathrm{w}, \mathrm{t}} \quad$ Thermal resistance of non-insulated wall, $\left(\mathrm{m}^{2} \mathrm{~K} / \mathrm{W}\right)$

$\mathrm{T} \quad$ Temperature $(\mathrm{K})$

$\mathrm{T}_{\mathrm{r}} \quad$ Reference temperatures of cold storage

$\mathrm{U} \quad$ Total heat transfer coefficient, $\left(\mathrm{W} / \mathrm{m}^{2} \mathrm{~K}\right)$

$\mathrm{x} \quad$ Insulation material thickness, $(\mathrm{m})$

$\mathrm{x}_{\mathrm{opt}, \mathrm{c}} \quad$ Optimum insulation thickness, (m)

XPS Extruded polystyrene

\section{Subscripts}

A annual

C cooling

e electricity

ins insulation

o outside

opt optimum

t total

\section{REFERENCES}

[1] Özel M. Effect of insulation location on dynamic heat-transfer characteristics of building external walls and optimization of insulation thickness. Energy and Buildings 2014;72:288-295. https://doi.org/10.1016/j.enbuild.2013.11.015

[2] Güllüce H, Karslı S, Saraç H. Konutlarda Yalıtım Kalınlıklarının Artırılmasının Enerji Tasarrufuna Etkisi. Ulusal İklimlendirme Kongresi 18-20 Nov. 2011, Antalya, Turkey.

[3] Yılmaz Hİ. Soğuk Hava Depolarında Kullanılan Farklı Yapı Malzemelerin Yalıtım ve Enerji Tasarrufu Özellikleri Üzerine Etkilerinin Karşılaştırmalı Olarak Değerlendirilmesi. Fruit Research Institute 2017;1: 154-160. ISSN: 2148-0036

[4] Aytaç A, Aksoy UT. Enerji Tasarrufu İçin Dış Duvarlarda Optimum Yalıtım Kalınlığı ve Isıtma Maliyeti İlişkisi, Journal of Gazi University Faculty of Engineering and Architecture 2006;21:753-758.

[5] Kaynaklı Ö, Yamankaradeniz R. Isıtma Süreci ve Optimum Yalıtım Kalınlığı Hesabı. TMMOB Tesisat Mühendisliği Dergisi 2008;104:19-25.

[6] Oğulata RG. Sectoral Energy Consumption in Turkey. Renewable and Sustainable Energy Reviews 2002;6: 471-480. https://doi.org/10.1016/S1364-0321(02)00012-6

[7] Kaygusuz K, Kaygusuz A. Energy and Sustainable Development Part II: Environmental İmpacts of Energy Use. Energy Sources 2004;26:1071-1082. https://doi.org/10.1080/00908310490441412 
[8] Kürekci NA, Bardakçı AT, Çubuk H, Emanet Ö. Türkiye'nin Tüm İlleri İçin Optimum Yalıtım Kalınlığının Belirlenmesi. TMMOB Tesisat Mühendisliği Dergisi 2012;131:5-21.

[9] Özkan DB, Onan C. Optimization of insulation thickness for different glazing areas in buildings for various climatic regions in Turkey. Applied Energy 2011;88:1331-1342. https://doi.org/10.1016/j.apenergy.2010.10.025

[10] Özel M. Effect of wall orientation on the optimum insulation thickness by using a dynamic method. Applied Energy 2011;88:2429-2435. https://doi.org/10.1016/j.apenergy.2011.01.049

[11] Ashouri M, Astaraei FR, Ghasempour. R, Ahmadi M.H, Feidt M. Optimum insulation thickness determination of a building wall using exergetic life cycle assessment. Applied Thermal Engineering 2016; 106:307-315. https://doi.org/10.1016/j.applthermaleng.2016.05.190

[12] Ertürk M, Keçebaş A, Daşdemir A, Kurt H. Isıtma ve Soğutma Uygulamalarında Optimum Yalıtım Kalınlı̆̆ ve Enerji Tasarrufu Analizi. 10th International Clean Energy Symposium 24-26 October 2016, p. 496-506. Istanbul, Turkey.

[13] Liu X, Chen Y, Ge H, Fazio P, Chen G, Guod X. Determination of optimum insulation thickness for building walls with moisture transfer in hot summer and cold winter zone of China. Energy and Buildings 2015;109:361-368. https://doi.org/10.1016/j.enbuild.2015.10.021

[14] Dağıdır C, Bolattürk A. Sıcak İklim Bölgelerindeki Binalarda Isıtma ve Soğutma Yüküne Göre Tespit Edilen Optimum Yalıtım Kalınlıklarının Karşılaştııılması. TMMOB Tesisat Mühendisliği Dergisi 2011;124:64-77.

[15] Vincelas FFC, Ghislain T. The determination of the most economical combination between external wall and the optimum insulation material in Cameroonian's buildings. Journal of Building Engineering 2017;9:155163. https://doi.org/10.1016/j.jobe.2016.12.008

[16] Derradji L, Imessad K, Amara M, Errebai FB. A study on residential energy requirement and the effect of the glazing on the optimum insulation thickness. Applied Thermal Engineering 2017;112:975-985. https://doi.org/10.1016/j.applthermaleng.2016.10.116

[17] Ozer M. Determination of optimum insulation thickness based on cooling transmission load for building walls in a hot climate. Energy Conversion and Management 2013;66:106-114. https://doi.org/10.1016/j.enconman.2012.10.002

[18] Sanea SAA, Zedan MF. Improving thermal performance of building walls by optimizing insulation layer distribution and thickness for same thermal mass. Applied Energy 2011;88:3113-3124. https://doi.org/10.1016/j.apenergy.2011.02.036

[19] Daouas N, Hassen Z, Aissia HB. Analytical periodic solution for the study of thermal performance and optimum insulation thickness of building walls in Tunisia. Applied Thermal Engineering 2010;30:319-326. https://doi.org/10.1016/j.applthermaleng.2009.09.009

[20] Nematchoua MK, Ricciardi P, Reiter S, Yvon A. A comparative study on optimum insulation thickness of walls and energy savings in equatorial and tropical climate. International Journal of Sustainable Built Environment 2017;6:170-182. https://doi.org/10.1016/j.ijsbe.2017.02.001

[21] TS 825, Binalarda Isı Yalıtım Kuralları, Turkish Standards Institute, 1998.

[22] Parameters of the insulation. www.izocam.com.tr

[23] Prices of electricity, 2018. http://enerjienstitusu.de/elektrik-fiyatlari/

[24] Inflation rate, Agu. 2018.http://www.tcmb.gov.tr

[25] Average external weather temperatures of cities. https://www.mgm.gov.tr

[26] Pusat Ş, Ekmekçi İ, Dündar AÇ, Ermiş K, Şen Y. İstanbul İçin Tipik Meteorolojik Yıl ve Derece-Saat Hesabı. 2. Ulusal İklimlendirme Soğutma Eğitimi Sempozyumu ve Sergisi Oct. 23-25 2014, Balıkesir, Turkey.

[27] Kumar D, Kumar S, Bhayo BA, Harijan K, Uqali MA. Economic and environmental impacts of thermal insulation used in different duct size. Journal of Thermal Engineering 2020;6:1:141156. https://doi.org/10.18186/thermal.672085

[28] Kurekci NA, Özcan M. A practical method for determination of economic insulation thickness of steel, plastic and copper hot water pipes. Journal of Thermal Engineering 2020;6:1:72-86. https://doi.org/10.18186/thermal.671651 